\title{
Proefschrift
}

\section{Computer-based nutrition education for general practice. Development of a training program and effect assessment by standardized patients}

Maiburg B (25 juni 2003). Computer-based nutrition education for general practice. Development of a training program and effect assessment by standardized patients. Universiteit Maastricht.
Promotoren: prof. dr. J.W. van Ree, prof. dr. E.M.H. Mathus-Vliegen. [s.l.]: [s.n.]; 2003. 147 pagina's. ISBN 90-5278-377-2.

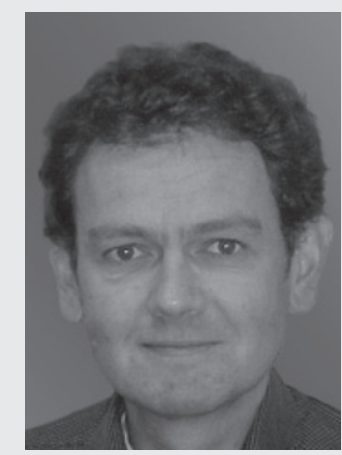
Naam
Bas Maiburg
$1973-1980$
Studie geneeskunde, Katholieke Universiteit Leuven (België)
1981 - 1982 Huisartsopleiding, Erasmus Universiteit, Rotterdam
1983 - 1997 Huisarts in Eindhoven/Heerlen
1991 - 2001 Huisartsbegeleider, afdeling Huisartsopleiding,
Maastricht
2001 - heden Aioscoördinator afdeling Huisartsopleiding,
Maastricht, en actief betrokken geweest bij het
in maart 2006 afgesloten project 'Vernieuwing
Huisartsopleiding' (o.a. de ontwikkeling van een
competentieprofiel van de huisarts en een landelijk opleidingsplan)

Dit proefschrift richtte zich op het verbeteren van de kennis, vaardigheden en attitude van huisartsen-in-opleiding (aios huisartsgeneeskunde) op het gebied van voeding door middel van een computerondersteund onderwijsprogramma (COO). Het onderzoek viel in twee delen uiteen:

1. De ontwikkeling van het COO 'Voeding' met als algemene onderzoeksvraag: "Hoe kan het COO het beste ontwikkeld worden, rekening houdend met de bij het ontwikkelen van onderwijs standaard vereiste onderwijskundige elementen?"

2. De effectmeting van het programma met als vraag: "In welke mate verbetert het COO de feitenkennis (competence) en het feitelijk handelen in de dagelijkse praktijk (performance) van aios huisartsgeneeskunde?"

In het ontwikkelingsdeel van het onderzoek startten we met het bepalen van de beginsitu- atie van aios huisartsgeneeskunde op voedingsgebied aan de hand van een enquête onder alle aios huisartsgeneeskunde. De lijst betrof een aan aios aangepaste versie van de bij huisartsen gebruikte en gevalideerde Wageningen GPs Nutrition Practices Questionnaire. Vrijwel alle aios beschouwden voedingsvoorlichting als een belangrijke taak en $89 \%$ van hen vond het geintegreerd behandelen van voedingsaspecten bij medisch-inhoudelijk onderwijs belangrijk tot zeer belangrijk. Als belangrijkste barrières ervaarden aios een gebrek aan voedingskennis en vaardigheden, én tijd in de praktijk. De op basis van de enquête ontwikkelde modellen met betrekking tot voedingsvoorlichting en -beleid door aios kwamen sterk overeen met de modellen bij huisartsen.

Vervolgens voerden we een Delphi-onderzoek uit onder een groep huisartsen om de onderwerpen vast te stellen waaraan vanuit de 
praktijk gezien behoefte bestond aan nascholing. In twee rondes kwamen we tot een prioriteitenlijst van ziektegerelateerde voedingsonderwerpen met zeer hoge overeenstemming onder de respondenten. De top vijf van de lijst (gewichtsproblematiek, diabetes mellitus, hypercholesterolemie, darmklachten en hypertensie) gebruikten we voor het vaststellen van de leerinhoud van het $\mathrm{COO}$ 'Voeding'.

Als basis voor het $\mathrm{COO}$ 'Voeding' kozen we na het voorleggen van een aantal modellen aan praktiserende huisartsen - voor een computersimulatie van huisartsenconsulten, waarbij de gebruiker aan de hand van een aantal schermen de verschillende onderdelen van een consult doorloopt. In het $\mathrm{COO}$ volgt na de consultfase een feedbackgedeelte waarin de keuzes van de gebruiker vergeleken worden met de keuzes van een huisarts-expert. Zowel in de consultals feedbackfase bieden video's van een huisarts-expert extra praktijkcontext. De gebruiker kan zijn eigen route door de simulatie bepalen. Zowel de menustructuur van de simulatie als de casuïstiek ontwierpen we met behulp van een panel van (huisarts)voedingsexperts. In totaal bestaat het $\mathrm{COO}$ 'Voeding' uit 12 casus over de top vijf uit de Delphi-studie.

Aan de effectmeting van het onderzoek ging de nodige voorbereiding vooraf. Voor de competencemeting ontwikkelden we een kennistoets over voeding in drie stappen: (1) het vaststellen van het toetsdomein; (2) het ontwerpen van een blauwdruk voor de toets; en (3) een analyse van de kernproblemen uit de casuïstiek van het $\mathrm{COO}$ 'Voeding'. Bij de performancemeting kozen we voor het inzetten van incognito simulatiepatiënten (SP's) in de huisartspraktijken waar de aios werkten. Hiervoor trainden we een groep nieuw geworven SP's uitgebreid voor hun rol en het invullen van de checklists, die in samenwerking met het panel van (huisar ts)voedingsexperts ontwikkeld waren. De keuze om SP's in te zetten als zogenaamde 'bekende' patiënt betekende dat in alle betrokken 50 praktijken patiëntenkaarten aangemaakt moesten worden voor iedere SP. Bovendien maakten we voor iedere SP een map met gegevens over de te bezoeken praktijk aan (met o.a. praktijkgegevens, foto's en plattegronden) zodat de SP zich op natuurlijke wijze als 'bekende' patiënt kon gedragen.

De effectmeting bestond uit een op het groepsniveau van aios gerandomiseerde, gecontroleerde trial. Van de in totaal 49 deelnemende aios vormden 25 aios de interventiegroep die het $\mathrm{COO}$ 'Voeding' tijdens en in aanvulling op hun terugkomdagprogramma volgden. Gemiddeld besteedden zij zes uur aan het COO. De overige aios volgden alleen het reguliere terugkomdagprogramma en vormden de controlegroep. Zowel vóór als na de interventie maakten alle aios de kennistoets over voeding en werden zij tijdens hun spreekuur door drie incognito SP's bezocht.

De relatieve verbetering van de scores op de kennistoets tussen voor- en nameting bedroeg $40 \%$ voor de interventiegroep. Gecorrigeerd voor de verschillen tussen de onderzoeksgroepen in de voormeting was het verschil in scores tussen de interventie- en controlegroep $9.2 \%$ in de nameting. Dit hield, gerelateerd aan de gemiddelde score tijdens de voormeting, een verbetering van $28 \%$ binnen de interventiegroep in. De vergelijkbare scores op de SP-consulten waren:

1. Een relatieve verbetering tussen de voor- en nameting van de interventiegroep van $80 \%$.

2. Een gecorrigeerd verschil tussen de onderzoeksgroepen van $13.7 \%$, d.w.z. een verbetering van $68 \%$ in verhouding tot de gemiddelde voormetingsscore voor de interventiegroep.

Alle verschillen waren significant $(p<0.001)$ met uitzondering van een gecorrigeerd verschil op de kennistoets $(\mathrm{p}=0.002)$.

Bij verdere analyse van de SP-consulten bleken de in de vorige alinea genoemde verschillen ook significant voor iedere afzonderlijke casus én voor de verschillende onderdelen van de consulten (algemene anamnese, voedingsanamnese, lichamelijk onderzoek en voedingsbeleid). Bij het zoeken naar verstorende variabelen voor de resultaten van de kennistoets en de SP-consulten op basis van verschillen tussen praktijken, man/vrouw-verschillen en verschillen tussen de plaats van de basisopleiding, bleek alleen de plaats van de basisopleiding een verstorende variabele te zijn voor het consultonderdeel 'lichamelijk onderzoek'. Op basis van de correlaties tussen de verschillende SP-casus concludeerden we dat de effecten van het $\mathrm{COO}$ 'Voeding' casusonafhankelijk waren.

We zijn van mening dat het ontwikkelde $\mathrm{COO}$ 'Voeding' maatwerk levert voor de gebruiker en aios huisartsgeneeskunde op consistente wijze leert omgaan met voedingsgerelateerde medische problemen. Onderwerpen voor verder onderzoek omvatten het beklijven van het geleerde met het programma en de effectiviteit van het programma bij het gebruik door praktiserende huisartsen. 